\title{
Development of 21st Century Skills-Based Stereochemistry Learning Tools to Train Students' Argumentation Skills
}

\author{
Farah Erika*, Agung Rahmadani \\ Study Program of Chemistry Education, Faculty of Teacher Training and Education, \\ Mulawarman University \\ *Corresponding Author. Email: farah.erika@fkip.unmul.ac.id
}

\begin{abstract}
This study aims to describe the validity of 21 st century skills-based stereochemistry learning tools to train students' argumentation skills. This research is an educational design research with reference to the design of the Wademan development research model. The research instrument used was a learning tools validation sheet consisting of several validation sheets, namely: syllabus validation sheet, lesson plan validation sheet, teaching material validation sheet, student worksheet validation sheet, and argumentation skills assessment instrument validation sheet. The research data obtained from the validation and review sheets were analyzed descriptively and qualitatively. The expert's assessment of validation for each aspect of the assessment has good and very good validity criteria. These results indicate that learning tools that integrate the nature and complexity of the stereochemical structure of natural compounds from tropical rain forests can be used in the stereochemistry learning process.
\end{abstract}

\section{Article History}

Received: 29-08-2021

Revised: 23-09-2021

Accepted: 08-11-2021

Published: 11-12-2021

\section{Key Words:}

Stereochemistry

Learning Tools, 21st

Century Skills,

Argumentation Skills,

Tropical Rain Forest.

How to Cite: Erika, F., \& Rahmadani, A. (2021). Development of 21st Century Skills-Based Stereochemistry Learning Tools to Train Students' Argumentation Skills. Jurnal Kependidikan: Jurnal Hasil Penelitian dan Kajian Kepustakaan di Bidang Pendidikan, Pengajaran dan Pembelajaran, 7(4), 822-833. doi:https://doi.org/10.33394/jk.v7i4.4088

https://doi.org/10.33394/jk.v7i4.4088

This is an open-access article under the CC-BY-SA License.

\section{Introduction}

The development of science is based on progress in its field. By developing knowledge, one must be able to convince others through his discoveries. The findings must also be convincing through good quality argumentation. Scientists use arguments to relate the evidence they choose to claims obtained through the use of warrants and backings (Jim'enezAleixandre \& Erduran, 2007). Argumentation is an important discourse process in science, and therefore should be implemented in science classrooms (Jiménez-Aleixandre et al., 2000; Kelly \& Takao 2002).

The ability in argumentation must be followed by argumentation quality. Argumentation quality is defined as a condition of presence refutation issued by a student in a study (Erduran et al. 2004; Erduran et al. 2015 ). The quality of argumentation is significant in understanding the study and developing thinking skills, such as critical thinking. Someone who can think critically if able to analyze, understand, and evaluate argumentation inside study activity.

Argumentation is the process of developing, explain, and evaluate the scientific argument. A scientific argument based on a specific claim or statement is justified to supported proof or data (Nuttfield Foundation, 2013a). Argumentation is a reasoning strategy located in the domain of informal reasoning and critical thinking (Jim'enez et al., 2000; Jim'enez-Aleixandre \& Erduran, 2007). Sampson and Clark (2008) differentiated with argument and argumentation by using "argument" that means the data used by student for articulate and justify claim or conclusion whereas "argumentation" to describe process 
overall. From differences meaning about argumentation, at least two points that combined in definition van Eemeren and Grootendorst relevant to science class contextual, which are argumentation as a justification of knowledge and argumentation as persuasion. Therefore, argumentation in scientific topics could be defined as the relationship between claim and data through justification or evaluation claim of expertise in proof, either empirically or theoretically (Jimenez-Aleixandre and Erduran, 2007). Studies, including argumentation as challenging for students; as an example, students are always asked how to explain "why and how things can happen" in the organized activity to involve students argue.

In the Covid-19 pandemic era, have occurred necessary changes in the implementation of organic chemistry study. Organic chemistry using the various symbol in representation which should understand by students (Taber, 2009), and the things impact on difficulties that faced students with understanding organic chemistry concepts (Bhattacharyya \& Bodner, 2005; Ferguson \& Bodner, 2008; Cartrette \& Dobberpuhl, 2009; Kraft et al., 2010; Dwyer \& Childs, 2011; Cartrette \& Mayo, 2011; Cooper et al., 2012). Students usually tend to use a study approach oriented with memorization (Duffy, 2006). According to Garlich (2015), cognitive skills to understand organic chemistry were representational competency, spatial ability, and scientific reasoning strategy. In their research, Chin \& Osborne (2010) mentioned that implementation from the thinking process and scientific reasoning process is argumentation. Understanding the relationship between scientific argumentation verbal and written were convinced can help fruitfulness in organic chemistry study (Pabuccu et al., 2012). The study focused on argumentation can increasing student conceptual comprehension (Venville \& Dawson, 2010; Aydeniz et al., 2012; Walker \& Sampson, 2013a; Cetin, 2014) and quality argumentation (Erduran et al., 2004; Garcia et al., 2013). The low argumentation skill influenced the low on chemistry concept comprehension (Cetin, 2014; Sekerci \& Canpolat, 2014; Aydeniz et al., 2012). During the pandemic era, students much more obtained presentation materials from lecturers and tend only to wait for lecturer presentation slides and memorize the materials. These things impact on liveliness and argumentation strength from students. Consequently, it needed a study model to develop a student's argumentation strength in understanding organic chemistry subjects.

The development of organic chemistry syllabus directing material contents appropriate with Pola Ilmiah Pokok (PIP) Mulawarman University concentrated on natural resources, mostly tropical rain forest and its environment. As known as tropical rain forest as a warehouse of chemistry compounds, natural resources, particularly plants that exist inside it, are sourced from chemistry compounds in particular organic compounds that can be implemented as origin examples of subject material on organic chemistry I. For example, $(+) /(-)-c a t h e c h i n$ isolated from stem bark of Aglaia elliptica (Meliaceae) and Chisocheton pentandrus (Meliaceae). Both of these plant species are found in Indonesia's tropical forest. The chirality and complexity of stereochemistry in natural products of rain forests can be used as learning resources in developing organic chemistry learning. So it's necessary to develop integrated organic chemistry learning tools PIP UNMUL based on $21^{\text {st }}$ century skills to practice atudent argumentation skill, because with existence example that comes from the surrounding environment makes students have interest and comprehension better in argue skill in organic chemistry I subject.

\section{Research Method}

Producing integrated stereochemical learning tools for UNMUL Principal Scientific Patterns (PIP) based on 21st-century skills to train students' argumentative skills as a valid (Nieveen, et al., 2007; Plomp \& Nieveen, 2013) is the aim of this study. The learning tools 
developed must be of high quality according to the validator's assessment, must be realistic and can be applied by lecturers and students. The learning tools' application produces the desired impact accompanied by positive student response to stereochemical learning tools. This research was conducted at Mulawarman University from October to December 2020. The scope of this research is Chemistry Education Department students enrolled in class I Organic Chemistry for the 2020/2021 academic year, totaling 100 students. The research focused on the stage of developing 21 st century skills-based stereochemistry learning tools by qualitatively analyzing the results of the validator's assessment.

The researcher chose the Wademan development research model (Plomp \& Nieveen, 2013) as a reference for developing stereochemical learning tools. This model illustrates that the approach and product (intervention) go hand in hand with the approach and theory (design principles). The term generic refers to the theory as a result of research that can describe intervention theory or design theory, namely the knowledge generated from research. Theoretical and empirical support is needed in the prototype design process to obtain information about the quality of interventions and design principles. Formative evaluation exists as an essential feature and is placed in educational design research from the model developed by Wademan (in Plomp \& Nieveen, 2013). The researcher chose this model to design the stereochemical learning tools developed in this study. The steps to build the Wademan model include 1) identification of the problem, 2) tentative identification of the product and design principles, 3) tentative theory and product, 4) prototyping and assessing product quality, and 5) improving product quality.

Experts use the instrument in the form of a validation sheet to assess the learning tools' quality being developed. Experts review and evaluate the quality of each component of each learning device. The instrument for measuring this learning device's validity consists of several validation sheets: the syllabus validation sheet, the lesson plan validation sheet, the teaching material validation sheet, the student worksheet validation sheet, and the assessment instrument validation sheet. The average score for each aspect calculates the data obtained from the validation of learning tools by experts. The technique of analyzing the validity of the learning tools uses descriptive qualitative.

Table 1. Evaluation Criteria for the Validation of Stereochemical Learning Tools

\begin{tabular}{lll}
\hline \multicolumn{1}{c}{ Score Interval } & \multicolumn{1}{c}{ Assessment criteria } & \multicolumn{1}{c}{ Information } \\
\hline $3.25<\mathrm{P} \leq 4.00$ & Very valid & Can be used without revision \\
$2.50<\mathrm{P} \leq 3.25$ & Valid & Can be used with minor revisions \\
$1.75<\mathrm{P} \leq 2.50$ & Invalid & Can be used with multiple revisions \\
$1.00 \leq \mathrm{P} \leq 1.75$ & Very invalid & $\begin{array}{l}\text { Not yet usable and still requires } \\
\text { consultation }\end{array}$ \\
& &
\end{tabular}

(Adaptation of Ratumanan and Laurens, 2006)

The reliability of the learning tools validation sheet is determined based on the Percentage of observer agreement (Borich, 2003) by looking at the learning tools validation sheet's consistency when used to validate by the validator. The learning tools developed were then applied to organic chemistry learning online. Learning uses synchronous platforms such as zoom meetings and asynchronous such as WhatsApp group, Mulawarman University Online System (MOLS), YouTube, and Google Forms. The response questionnaire is used to determine student responses to the use of the learning tools developed. The results of the questionnaire were analyzed descriptively qualitatively. 


\section{Results and Discussion}

The stereochemistry learning tools developed to consist of syllabus, lesson plans, teaching materials, student worksheet, and argumentation skills assessment sheets. The results of expert assessments of learning tools were carried out on content validity, construct validity, and the use of language in stereochemical material.

\section{1). Results of the validation of the syllabus}

A summary of the validation analysis results for each component of the syllabus is shown in Table 2.

Table 2. Results of Syllabus Validation

\begin{tabular}{clcccl}
\hline No. & $\begin{array}{c}\text { Assessment } \\
\text { Aspects }\end{array}$ & $\begin{array}{c}\text { Validation } \\
\text { Score }\end{array}$ & Criteria & $\begin{array}{c}\text { Reliability } \\
\text { Coefficient } \mathbf{( \% )}\end{array}$ & Reliability \\
\hline 1. & Format & 3,27 & Very valid & 89 & Reliable \\
2. & Contents & 3,54 & Very valid & 95 & Reliable \\
3. & Language & 3,89 & Very valid & 95 & Reliable \\
\hline
\end{tabular}

The criteria for the validity of the syllabus validation components based on Table 2 all met the very valid criteria. The level of consistency between experts on all parts of the syllabus validation is very high.

The syllabus can be used as a guide in preparing a learning framework in the form of lesson plans, teaching materials, student worksheets, and assessment sheets (Fink, 2012; Ludy et al., 2016). The components of a validated syllabus include: 1) A syllabus is made for each meeting; 2) Syllabus identity (title, study program, courses, semester, number of credits, and learning outcomes); and 3) Format of syllabus table (expected final ability, indicators, learning experience, subject matter, time allocation, learning resources, and assessments, and references). The developed syllabus format component accommodates the Regulation of the Minister of Research, Technology and Higher Education of the Republic of Indonesia Number 44 of 2015 concerning National Higher Education Standards, which requires a description of the learning outcomes of KKNI graduates, namely, includes a description of attitudes and values, workability, mastery of knowledge and authority and responsibility.

\section{2). Results of the validation of the lesson plan}

The results of the validation analysis for each component of the lesson plan are shown in Table 3.

Table 3. Results of Lesson Plan Validation

\begin{tabular}{clcccl}
\hline No. & $\begin{array}{c}\text { Assessment } \\
\text { Aspects }\end{array}$ & $\begin{array}{c}\text { Validation } \\
\text { Score }\end{array}$ & Criteria & $\begin{array}{c}\text { Reliability } \\
\text { Coefficient (\%) }\end{array}$ & Reliability \\
\hline 1. & Format & 3,60 & Very valid & 92 & Reliable \\
2. & Contents & 3,39 & Very valid & 97 & Reliable \\
3. & Language & 3,78 & Very valid & 95 & Reliable \\
\hline
\end{tabular}

Based on Table 3, the lesson plan validation components' validity all meet the very valid criteria. The level of consistency between experts on all elements of the lesson plan validation is very high.

The lesson plan is developed based on the syllabus, describes, and directs learning activities to achieve the expected learning outcomes and final abilities. RPP is a plan that describes and regulates the learning process to achieve one of the basic competencies in the syllabus (Ahmad and Nur, 2015). The learning steps in the lesson plans developed have been 
adapted to argument-based online learning. The lesson plan communicates to students what they will learn and how they will be assessed and helps lecturers organize content, materials, time, strategies, and assistance in the classroom by coordinating learning components so that learning objectives, learning materials, how to deliver activities (method, models and techniques) and how to evaluate them are clear and systematic so that the teaching and learning process becomes effective and efficient (Susantini, 2009: Ahmad \& Nur, 2015; Widodo, 2017). The RPP developed has fulfilled the form of a good learning plan based on SNPT and KKNI (Kemendikbud, 2014; Widodo, 2017), which states that the lesson plan includes: 1) RPP identity (title, department, study program, course, semester, subject matter, number of credits, meetings too, time allocation, learning outcomes), 2) Systematics of RPP content (expected final abilities and indicators, learning stages, learning activities, approaches/models/methods, media, time allocation, learning resources, assessment, and Bibliography).

\section{3). The results of the validation of teaching materials}

A summary of the validation analysis results for each component of the teaching material is shown in Table 4.

Table 4. Results of Teaching Material Validation

\begin{tabular}{llcccc}
\hline No. & \multicolumn{1}{c}{$\begin{array}{c}\text { Assessment } \\
\text { Aspects }\end{array}$} & $\begin{array}{c}\text { Validation } \\
\text { Score }\end{array}$ & Criteria & $\begin{array}{c}\text { Reliability } \\
\text { Coefficient (\%) }\end{array}$ & Reliability \\
\hline 1. & Format & 3,60 & Very valid & 92 & Reliable \\
2. & Contents & 3,39 & Very valid & 97 & Reliable \\
3. & Language & 3,78 & Very valid & 95 & Reliable \\
4. & Presentation & 3,78 & Very valid & 95 & Reliable \\
5. & Assessment of & 3,50 & Very valid & 90 & Reliable \\
& teaching materials & & & & \\
& in supporting & & & & \\
& innovation and & & & & \\
& improving the & & & & \\
& quality of teaching & & & & \\
& and learning & & & \\
& activities & & & \\
\hline
\end{tabular}

The validity of the components of the validation of teaching materials is based on Table 4, all of which meet the very valid criteria. The level of consistency between experts on all components of the validation of teaching materials is very high.

Teaching materials are essential learning materials in the learning process to help students understand concepts and make it easier to achieve each student's competencies (Prasetiyo \& Perwaningtyas, 2017; Ilma and Wijarini, 2017; Ningsih et al., 2018). Stereochemical teaching materials are integrated with PIP Unmul, which is equipped with several examples of the structure of secondary metabolite compounds derived from wet tropical forest plants. Some features are expected to help students understand the material and practice argumentation skills. In the feature "let's understand," students are reminded of the material studied so that students can set the learning objectives carried out. In the "let's look at" feature, students are given examples of problems whose argument solutions are presented in a graphic organizer. In the "let's find out" feature, students are encouraged to carry out investigative activities with their friends' group. Meanwhile, the "let's test understanding" 
feature is a student activity that tests the student's ability to argue in understanding the material that has been studied. Student responses show $68.18 \%$ of students are quite easy to use components in teaching materials. This means that the developed teaching material can help practice argumentation skills in students. In line with the research results of Sari et al. (2017) and Alberida et al. (2018), which revealed that the use of teaching materials developed according to the materials and skills that will be taught to students during the learning process could improve the expected skills compared to conventional teaching materials. As many as $80.03 \%$ of students felt interested in using teaching materials. Students also stated that stereochemistry teaching materials were new $(81.31 \%)$. This data indicates that students are interested in reading teaching materials and motivated to learn more. This is in line with the research of Wulanzani et al. (2016) and Adalikwu \& Iorkpligh (2013), which stated that students' interest in reading teaching materials is because teaching materials can act as facilitators between lecturers and students and develop student motivation during learning activities.

The teaching materials developed are based on learning outcomes and final abilities in the stereochemical syllabus. The development of such teaching materials is following the opinion of Mulyasa (2007) and Wulanzani et al. (2016), which state that the teaching material developed must be able to support the learning process and display the integrity of the competencies that will be mastered by students in learning activities so that it can help the achievement of course competencies. Development of stereochemical teaching materials based on the KKNI-based curriculum, which refers to the description of the learning outcomes of KKNI graduates, namely, including descriptions of attitudes and values, workability, mastery of knowledge and authority, and responsibility. The development of teaching materials that are under the curriculum is based on the opinion of Cardoso et al. (2009), which states that teaching material is the main link not only between lecturers and students but also between learning objectives because the teaching material in it seeks to translate the principles proposed by the curriculum, the teaching material contains content and activities that students can assimilate. The developed student teaching material can be used to improve argumentation skills because there are features specifically designed to practice these skills. The arguing skills-based teaching material developed is in line with the guidelines for preparing learning tools and teaching materials of the Ministry of Research, Technology and Higher Education (2017) that the appropriateness of the content of teaching materials can develop life skills.

\section{4). Results of student worksheet validation}

A summary of the validation scores for each component of the student worksheet is shown in Table 5.

Table 5. Results of Student Worksheet Validation

\begin{tabular}{clclcl}
\hline No. & \multicolumn{1}{c}{$\begin{array}{c}\text { Assessment } \\
\text { Aspects }\end{array}$} & $\begin{array}{c}\text { Validation } \\
\text { Score }\end{array}$ & Criteria & $\begin{array}{c}\text { Reliability } \\
\text { Coefficient } \mathbf{( \% )}\end{array}$ & Reliability \\
\hline 1. & Format & 3,83 & Very valid & 93 & Reliable \\
2. & Contents & 3,33 & Very valid & 97 & Reliable \\
3. & Language & 3,89 & Very valid & 95 & Reliable \\
4. & Presentation & 3,25 & Very valid & 93 & Reliable \\
5. & Assessment of & 3,24 & Very valid & 90 & Reliable \\
& teaching materials & & & & \\
\hline
\end{tabular}




\section{in supporting \\ innovation and \\ improving the \\ quality of teaching \\ and learning \\ activities}

The expert's assessment of the validation of the developed student worksheets is valid and very valid. The level of consistency between experts on all components of student worksheet validation is very high.

Stereochemistry student worksheets were developed by integrating Unmul's PIP. Student worksheets with examples of structures for secondary metabolites from tropical wet forests. Student worksheets are designed with activities that encourage students to do argumentation skills according to the directions contained in student worksheets and understand chemical materials. The activities carried out by students in student worksheets include: identifying chemical problems, formulating problems, proposing hypotheses, formulating learning objectives, carrying out investigative activities, making arguments, presenting chemical arguments, and making conclusions. Graphic organizer chemistry arguments made by students in making arguments are characteristics of student worksheets that can practice argumentation skills. As stated by Bulgren and Ellis (2012), graphic organizers provide space for each step of the argumentation process. Student worksheets developed according to the material and skills framework that will be taught to students are needed in the learning process so that activities carried out by students can be directed (Supeno et al., 2015). Student worksheets can direct student learning activities to help students understand the material, solve problems, and help students discuss (Kibar \& Ayas, 2010; Demoin \& Jurisson, 2013). Development of student worksheets is carried out based on learning outcomes, final abilities, and indicators on the syllabus and stereochemical lesson plans. Developing student worksheets must be done by paying attention to the lesson plans and syllabus that have been developed (Widodo et al., 2018). Students feel interested in using student worksheets $(75.25 \%)$; students also state that stereochemistry student worksheets are quite easy to use $(66.62 \%)$. This data shows that students are interested in using student worksheets because they state that the students' worksheets are new (81.31\%). This is because student worksheets are also equipped with references to read more about the material discussed (Susanti et al., 2018).

\section{5). The validation results of the argumentation skills assessment sheet}

A summary of the assessment sheet validation for arguing skills is shown in Table 6 .

Table 6. Validation Results of the Argumentation Skills Assessment Sheet

\begin{tabular}{lllcccc}
\hline No. $\begin{array}{l}\text { Assessment } \\
\text { Aspects }\end{array}$ & $\begin{array}{c}\text { No. } \\
\text { Questions }\end{array}$ & $\begin{array}{l}\text { Validati } \\
\text { on Score }\end{array}$ & Criteria & $\begin{array}{l}\text { Reliability } \\
\text { Coefficient } \\
(\%)\end{array}$ & Reliability \\
\hline 1. & Theory & 1 & 3,50 & Very & 86 & Reliable \\
& 2 & 3,33 & valid & 90 & Reliable \\
& 3 & 3,42 & Very & 90 & Reliable \\
& 4 & 3,42 & valid & 90 & Reliable \\
& $5 \mathrm{a}, 5 \mathrm{~b}$ & 3,42 & $\begin{array}{l}\text { Very } \\
\text { valid }\end{array}$ & 86 & Reliable \\
& & & & \\
\hline
\end{tabular}




\begin{tabular}{|c|c|c|c|c|c|c|}
\hline & & & & $\begin{array}{l}\text { Very } \\
\text { valid } \\
\text { Very } \\
\text { valid }\end{array}$ & & \\
\hline \multirow[t]{10}{*}{2.} & Instructions & 1 & 3,50 & Very & 93 & Reliable \\
\hline & & 2 & 3,50 & valid & 93 & Reliable \\
\hline & & 3 & 3,50 & Very & 93 & Reliable \\
\hline & & 4 & 3,67 & valid & 100 & Reliable \\
\hline & & $5 a, 5 b$ & 3,50 & Very & 93 & Reliable \\
\hline & & & & valid & & \\
\hline & & & & Very & & \\
\hline & & & & valid & & \\
\hline & & & & Very & & \\
\hline & & & & valid & & \\
\hline \multirow[t]{10}{*}{3.} & Language & 1 & 3,42 & Very & 90 & Reliable \\
\hline & & 2 & 3,50 & valid & 93 & Reliable \\
\hline & & 3 & 3,42 & Very & 90 & Reliable \\
\hline & & 4 & 3,42 & valid & 90 & Reliable \\
\hline & & $5 a, 5 b$ & 3,50 & Very & 93 & Reliable \\
\hline & & & & valid & & \\
\hline & & & & Very & & \\
\hline & & & & valid & & \\
\hline & & & & Very & & \\
\hline & & & & valid & & \\
\hline
\end{tabular}

The expert's assessment of the validation of the argumentation skills assessment sheet developed has very valid criteria. The level of consistency between experts on all components of the validation skills argument is very high.

The argumentation skills assessment instrument is designed by integrating the Unmul PIP. The questions in the assessment instrument contain the structures of secondary metabolites from wet tropical forests. The argumentation skills assessment instrument adapts the assessment developed by Venville \& Dawson (2010). The argumentation skills developed include indicators of claiming claims, data, and guarantees. The Argumentation Skills assessment sheet's validation, as shown in Table 6, is included in the very valid and reliable criteria. Referring to the opinion of Kereh et al. (2015), Kurnia et al. (2017), Muhtarom et al. (2017), Muslim et al. (2017) which states that there are at least two basic characteristics that can be used as a reference for the quality of an instrument, namely reliability, and validity. The instrument is developed if it meets the valid and reliable criteria for the next stage of operational field testing or measurement. Thus the instrument of argumentation skills developed can be used to measure students' argumentation skills.

The learning tools developed to consist of syllabus, lesson plan, teaching material, student worksheets, argumentation skills assessment sheet. The results of expert assessment of stereochemistry learning tools are carried out on content validity, construct validity, and language use, with each assessment aspect having good and outstanding validity criteria. Further research can be carried out to test the practicality and effectiveness of stereochemical learning tools to improve students' argumentation skills. 


\section{Conclusion}

PIP UNMUL's integrated stereochemistry learning device has been declared valid both in content and construct. It can be used in stereochemistry learning, exploring, and empowering student potential through argumentation activities to teach stereochemical concepts.

\section{Recommendation}

Further research can be carried out by researchers and educators to test the practicality and effectiveness of stereochemistry learning tools to improve the argumentation skills of chemistry students. The innovations carried out by integrating the UNMUL PIP, namely humid tropical forests and a 21st century skill-based environment are expected to be an alternative solution to improve students' argumentation skills.

\section{References}

Adalikwu, S.A. \& Iorkpilgh, I.T. (2013). The influence of instructional materials on academic perfomance of senior secondary school students in chemistry in cross river state. Global Journal of Educational Research, 12, 39-45. DOI http://dx.doi.org/10.4314/gjedr.v12i1.6

Ahmad, D. \& Nur, H.K. (2015). Developing english lesson plans for the first students of SMA 18 Makassar based on the 2013 curriculum. ETERNAL (English, Teaching Learning, and Research Jounal), 1 (2), 187-200.

Alberida, H., Lufri, Festiyed, \& Barlian, E. (2018). Problem Solving Model for Science Learning. IOP Conference Series: Materials Science and Engineering, 335, 012084. https://doi.org/10.1088/1757-899X/335/1/012084

Aydeniz, M., Pabuccu, A., Setin, P.S., \& Kaya, E. (2012). Argumentation and students's conceptual understanding of properties and behaviors of gases. International Journal of Science and Mathematics Education, 10(6), 1303-1324. https://doi.org/10.1007/s10763-012-9336-1

Bhattacharyya, G., \& Bodner, G.M. (2005). It gets me to the product: How Students Propose Organic Mechanisms. Journal of Chemical Education, 82, 1402-1407. DOI:10.1021/ed082p1402

Borich, G.D. (2003). Observation Skill for Effective Teaching. Fourth Edition. New Jersey: Pearson Education, Inc.

Bulgren, J.A. \& Ellis, J.D. (2012). Argumentation and Evaluation Intervention in Science Classes: Teaching and Learning with Toulmin. In M. S. Kwine (Eds.), Perspectives on Scientific Argumentation: Theory, Practice and Research (pp. 135-154). Dordrecht; New York: Springer.

Cardoso, D.C., Cristiano, M.P. \& Arent, C.O. (2009). Development of New Didactic Materials for Teaching Science and Biology: The Importance of the New Education Practices. OnLine Journal of Biological Sciences, 9 (1), 1-5. ISSN 1608-4217.

Cartrette, D. P., \& Dobberpuhl M. R. (2009). The concept inventory as a diagnostic of understanding and achievement in a year-long organic chemistry course. Chem. Educator, 14, 1-10.

Cartrette, D.P. \& Mayo, P.M. (2011). Students' understanding of acids/bases in organic chemistry contexts. Chem. Educ. Res. Pract., 2011, 12, 29-39. Doi: 10.1039/C1RP90005F

Cetin, P. S. (2014). Explicit argumentation instruction to facilitate conceptual understanding and argumentation skills. Research in Science \& Technological Education, 32(1), 120. https://doi.org/10.1080/02635143.2013.850071 
Chin, C., \& Osborne, J. (2010). Students' questions and discursive interaction: Their impact on argumentation during collaborative group discussions in science. Jounal of Research in Science Teaching. 47(10), 883-908. https://doi.org/10.1002/tea.20385

Cooper, M.M., Underwood, S.M., \& Hilley, C.Z. (2012). Development and validation of the implicit information from Lewis structures instrument (IILSI): do students connect structures with properties?. Chem. Educ. Res. Pract., 2012, 13, 195-200. DOI: 10.1039/C2RP00010E

Demoin, D.W . \& Jurisson, S.S. (2013). Chemical Kinetics Laboratory Discussion Worksheet. J. Chem. Educ. 90 (9), 1200-1202. doi:10.1021/ed400059f.

Dwyer Anne O' \& Childs Peter (2011). Second level irish pupils' and teachers' view of difficulties in organic chemistry. ebook-esera2011-Odwyer. Retrieved from https://s3.amazonaws.com/academia.edu.documents/

Duffy, A.M. (2006). Students' ways of understanding aromaticity an electrophilic aromatic substitution reactions. (Doctoral dissertation). Retrieved from https://escholarship.org/uc/item/8mb6v54x

Erduran S., Simon S. \& Osborne J. (2004). TAPping into argumentation: developments in the application of Toulmin's argument pattern for studying science discourse. Science Education, 88(6), 915-933. DOI 10.1002/sce.20012

Erduran, S., Ozdem, Y., \& Park, J.-Y. (2015). Research trends on argumentation in science education: a journal content analysis from 1998-2014. International Journal of STEM Education, 2(1). https://doi.org/10.1186/s40594-015-0020-1

Ferguson, R. \& Bodner, G. M. (2008). Making sense of the arrow-pushing formalism among chemistry majors enrolled in organic chemistry. Chem. Educ. Res. Pract., 2008, 9, 102-113. 10.1039/B806225K

Fink, S.B. (2012). The Many Purposes of Course Syllabi: Which Are Essential and Useful. Syllabus, 1 (1), 1-12.

Garcia-Mila M., Gilabert S., Erduran S. \& Felton M. (2013). The effect of argumentative task goal on the quality of argumentative discourse. Science Education, 97(4), 497-523. DOI $10.1002 /$ sce. 21057

Graulich, N. (2015). The tip of the iceberg in organic chemistry classes: how do students deal with the invisible? Chemistry Education Research and Practice, 16(1), 9-21. https://doi.org/10.1039/C4RP00165F

Ilma, S. dan \& Wijarini, F. (2017). Developing of Environmental Education Textbook Based on Local Potencies. Jurnal Pendidikan Biologi Indonesia, 3 (3), 194-201. p-ISSN: 2442-3750; e-ISSN: 2527-6204.

Jim'enez-Aleixander, M.P., Rodri'guez, A.B., \& Duschl, R.A. (2000). Doing the lesson or Doing science: Argument in high school genetics. Science Education, John Wiley\&Sons Inc. 758-792.

Jim'enez-Aleixandre M.P., \& Erduran, Sibel. (2007). Argumentation in science education: An overview. In S. Erduran \& M.P. Jim'enez-Aleixandre (Eds.), Argumentation in Science Education: Perspectives from Classroom-Based Research (pp 3-28). Dordrecht: Springer Science + Business Media B.V.

Kelly, G.J., \& Takao, A.(2002). Epistemic Levels in Argument: An Analysis of University Oceanography Students'Use of Evidence in Writing. Science education, 2002, Wiley Periodicals Inc. 314-342.

Kementerian Pendidikan dan Kebudayaan. (2014). Buku Kurikulum Pendidikan Tinggi. Direktorat Pembelajaran dan Kemahasiswaan. Direktorat jenderal Pendidikan Tinggi. 
Kementerian Riset, Teknologi dan Pendidikan Tinggi. (2017). Panduan Penyusunan Perangkat Pembelajaran dan Bahan Ajar. Direktorat Pembelajaran dan Kemahasiswaan. Direktorat Pembelajaran.

Kereh, C.T., Liliasari, Tjiang, P.C. \& Sabandar, J. (2015). Validitas dan Realibilitas Instrumen Tes Matematika Dasar yang Berkaitan dengan Pendahuluan Fisika Inti. Jurnal Inovasi dan Pembelajaran Fisika, 2 (1), 36-46.

Kibar, Z. B., \& Ayas, A. (2010). Developing a worksheet about physical and chemical event. Procedia - Social and Behavioral Sciences, 2(2), 739-743. https://doi.org/10.1016/j.sbspro.2010.03.094

Kraft, A., Strickland, A.M., \& Bhattacharyya, G. (2010). Reasonable reasoning: multivariate problem-solving in organic chemistry. Chem. Educ. Res. Pract., 2010, 11, 281-292. Doi: 10.1039/C0RP90003F

Kurnia, F., Rosana, D. \& Supahar (2017). Developing Instruments using CIPP Evaluation Model in the Implementation of Portfolio Assessment in Science Learning. International Journal of Environmental \& Science Education, 12 (8), 1989-1998.

Ludy, M.J., Brackenbury, T., Folkins, J.Wm., Peet, S. H., Langendorfer, S.J., \& Beining, K. (2016). Student Impressions of Syllabus Design: Engaging Versus Contractual Syllabus. International Journal for the Scholarship of Teaching and Learning, 10 (2), $1-23$.

Muhtarom, Juniati, D. \& Siswono, T.Y.E. (2017). Pengembangan Angket Keyakinan terhadap Pemecahan Masalah dan Pembelajaran Matematika. Jurnal Ilmiah Pendidikan Matematika, 2 (1), 55-64.

Mulyasa, E. (2007). Kurikulum Tingkat Satuan Pendidikan. Bandung: PT. Remaja Rosdakarya.

Muslim, Suhandi, A. \& Nugraha, M.G. (2017). Development of Reasoning Test Instruments Based on TIMSS Framework for Measuring Reasoning Ability of Senior High School Student on the Physics Concept. IOP Conf. Series: Journal of Physics: Conf. Series 812 012108. MSCEIS. (pp.1-5). Bandung.

Nieveen, N., McKenney, S. \& Van den Akker (2007). In Nieveen, N., McKenney, S., Van de Akker (Eds.). Educational Design Research. New York: Routledge.

Ningsih, F., Suratno., \& Narulita, E. (2018). The Development of Student's Book Based on STEM (Science Technology Engineering and Mathematics) With LBL (Life Based Learning) Integration On The Subject of Biotechnology in Class XII Senior High School. Pancaran Pendidikan, 7 (3), 7-12.

Nuffield Practical Work for Learning: Argumentation. (2013). Argumentation and practical work - An introduction. Nuffield Foundation.

Pabuccu,A., Erduran, S. \& Moncada, A. (2012). Argumentation in organic chemistry education. Strand 7 Discourse and argumentation in science education. esera.org.

Plomp, T. \& Nieveen, N. (2013). Introduction to the Collection of Illustrative Cases of Educational Design Research. In Plomp, and Nieveen (Eds.), Educational Design Research-Part B: Illustrative Cases. Enschede, the Netherlands: SLO.

Prasetiyo, N.A. \& Perwiraningtyas, P. (2017). Pengembangan Buku Ajar Berbasis Lingkungan Hidup pada MataKuliah Biologi di Universitas Tribhuwana Tunggadewi. Jurnal Pendidikan Biologi Indonesia, 3 (1), 19-27.

Sampson, V., \& Clark, D.B. (2008). Assessment of the Ways Students Generate Arguments in Science Education: Current Perspectives and Recommendations for Future Directions. Science Education, 2008, Wiley Periodicals Inc. 448-472. 
Sekerci, A. R., \& Canpolat, N. (2014). Impact of argumentation in the chemistry laboratory on conceptual comprehension of turkish students. Educational Process: International Journal, 3 (1-2), 19-34. https://doi.org/10.12973/edupij.2014.312.2

Supeno, Nur, M. dan Susantini, E. (2015). Pengembangan Lembar Kerja Siswa Untuk Memfasilitasi Siswa Dalam Belajar Fisika Dan Berargumentasi Ilmiah. Prosiding Seminar Nasional Jurusan Fisika FMIPA UM. (pp. 36-40). Malang.

Sari, B.P., Feranie, S. \& Winarno, N. (2017). The Use of Conceptual Change Text toward Students' Argumentation Skills in Learning Sound. J. Phys.: Conf. Ser. 895 012169, 15. doi :10.1088/1742-6596/895/1/012169.

Susantini, E. (2009). The Development of Biology Material Resources by Metacognitive Strategy. Jurnal Ilmu Pendidikan, 16 (2), 88-93.

Susanti, L. B., Poedjiastoeti, S., \& Taufikurohmah, T. (2018). Validity of worksheet-based guided inquiry and mind mapping for training students' creative thinking skills. Journal of Physics: Conference Series, 1006, 012015. https://doi.org/10.1088/17426596/1006/1/012015

Taber, S.K. (2009). Learning at The Symbolic Level: In J. K. Gilbert \& D. Treagust (Eds.), Multiple Representations in Chemical Education (pp. 75-106). Dordrecht: Springer.

Venville,G.J. \& Dawson, V.M. (2010). The impact of a classroom intervention on grade 10 students'argumentation skills, informal reasoning, and conceptual understanding of science. Journal of Research in Science Teaching. 47(8), 952-977.

Walker, J. \& Sampson, V. (2013). Learning to argue and arguing to learn in science: Argument-Driven Inquiry as a way to help undergraduate chemistry students learn how to construct arguments and engage in argumentation during a laboratory course. Journal of Research in Science Teaching, 50(50),561-596.

Widodo, C.S. (2017). Modul Penyusunan Rencana Pembelajaran Semester (RPS). Lembaga Pengembangan dan Penjaminan Mutu. Universitas Brawijaya.

Widodo, W., Sudibyo, E., \& Sari, D. A. P. (2018). Analysis of expert validation on developing integrated science worksheet to improve problem solving skills of natural science prospective teachers. Journal of Physics: Conference Series, 1006, 012026. https://doi.org/10.1088/1742-6596/1006/1/012026

Wulanzani, U.T., Lestari, U. \& Syamsyuri, I. (2016). Hasil Validasi Buku teks Matakuliah Bioteknologi Berbasis Bahan Alam Tanaman Pacing (Costus speciosus smith) sebagai Antifertilitas. Jurnal Pendidikan, 1 (9), 1830-1835. 